\title{
Nuclear Power and the Mob: Extortion and Social Capital in Japan
}

\section{Citation}

J. Mark Ramseyer, Nuclear Power and the Mob: Extortion and Social Capital in Japan (The Harvard John M. Olin Discussion Paper Series No. 817, Mar. 2015).

\section{Published Version}

http://www.law.harvard.edu/programs/olin_center/papers/pdf/Ramseyer_817.pdf

\section{Permanent link}

http://nrs.harvard.edu/urn-3:HUL.InstRepos:16883012

\section{Terms of Use}

This article was downloaded from Harvard University's DASH repository, and is made available under the terms and conditions applicable to Other Posted Material, as set forth at http:// nrs.harvard.edu/urn-3:HUL.InstRepos:dash.current.terms-of-use\#LAA

\section{Share Your Story}

The Harvard community has made this article openly available.

Please share how this access benefits you. Submit a story.

\section{Accessibility}




\section{HARVARD}

JOHN M. OLIN CENTER FOR LAW, ECONOMICS, AND BUSINESS

NUCLEAR POWER AND THE MOB:

EXTORTION AND SOCIAL CAPITAL IN JAPAN

J. Mark Ramseyer

Discussion Paper No. 817

03/2015

Harvard Law School

Cambridge, MA 02138

This paper can be downloaded without charge from:

The Harvard John M. Olin Discussion Paper Series:

http://www.law.harvard.edu/programs/olin_center/

The Social Science Research Network Electronic Paper Collection: $\underline{\text { http://ssrn.com/abstract }=2587276}$

This paper is also a discussion paper of the John M. Olin Center's Program on Corporate Governance. 
JEL: K14, L14, L94, Q4

Draft of March 31, 2015

Address correspondence to:

J. Mark Ramseyer

Harvard Law School

Ramseyer@law.harvard.edu

(617)496-4878

\title{
Nuclear Power and the Mob:
}

\section{Extortion and Social Capital in Japan}

\author{
By J. Mark Ramseyer*
}

\begin{abstract}
Nuclear reactors entail massive non-transferrable site-specific investments. The resulting appropriable quasi-rents offer the mob the ideal target. In exchange for large fees, it can either promise to "protect" the utility (and silence the reactor's local opponents) or "extort" from it (and desist from inciting local opponents). Using municipality-level (1742 cities, towns, villages) and prefecture-level (47) Japanese panel data covering the years from 1980 to 2010, I find exactly this phenomenon: when a utility announces plans to build a reactor, the level of extortion climbs.

Reactors have broad-ranging effects on social capital as well. In general, the perceived health costs to nuclear power are highest for young families. As a result, if a utility announces plans for a new reactor, these families disappear. Yet these are the men and women who invest most heavily in the social capital that keeps communities intact. When they disappear, reliance on government subsidies increases, and divorce rates rise. Firms stay away, and unemployment climbs.
\end{abstract}

* Mitsubishi Professor of Japanese Legal Studies, Harvard University. I gratefully acknowledge the hospitality of the University of Tokyo Law Faculty, and the generous financial support of the Harvard Law School. I received helpful comments and suggestions from Daniel Aldrich, Curtis Milhaupt, Eric Rasmusen, and workshop participants at the University of British Columbia, Harvard University, and Hitotsubashi University. 
The journalist had landed a job on the Fukushima cleanup crew (Suzuki, 2011: 910). As he chatted with the other workers, one of them explained his financial connection:

There's nothing special here. A huge public project comes to a tiny town. That's really all there is to it. Dams and highways are exactly the same. It's just that this one involves a nuclear power plant, and that's something no one understands.

[The local politicians] represent the town, and negotiate with the power company. They cut the deal with a general contractor. They spread the work to the locals.

But that would never get them enough workers.

So they talk to my friends in the other cities. They recruit companies with sympathetic bosses. Without us -- without the mob -- the work just would never get done. It'd never even get started. ...

Information about this kind of work comes straight to our place. We're the ones who assemble the votes for the elections. You could call it returning a favor, but it's just a case of relying on supporters to survive. ... Take the town council around here. Anyone we support will get elected.

The man switched tacks, and offered the journalist a suggestion:

You -- you're short of money, right? Why don't you move here? You could work a few years at our construction firm, and then run for office.

The mob (known colloquially as the "yakuza") had made enormous profits building nuclear plants, the informant insisted. But it did not just build the plants. It also smoothed the approval process (Suzuki, 2011: 24):

Why did we make so much money when a nuclear plant came to town?

It's obvious. We made money because we could make anyone who threatened to complain shut up.

In the article that follows, I trace some of these connections between nuclear power and the mob. In Japan as elsewhere, firms in the organized-crime industry invest in the personnel, skills, and technology needed to deliver violence. With it, they advance and protect their activities in illegal sectors. By simple economies of scope, however, sometimes they can exploit the same investments to other ends. Relevant here, they can use their investment in violence to extort funds from firms that compete in legal markets. If a developer invests heavily in preparation for a large and disruptive construction project, they can extort funds by manipulating (or threatening to manipulate) local opposition.

I also trace the connections between nuclear power and social cohesion. A nuclear reactor can devastate a community's social capital. Radiation risks are health risks, and the cost to those risks falls with age: rectors impose the highest perceived harm 
on young families. ${ }^{1}$ As a result, intact young couples do not move to communities building a reactor (especially with mob labor). They stay away. Yet these are the men and women who invest most heavily in the social ties that hold communities together. As they disappear, social capital disintegrates. Potential employers stay away. Jobs vanish, couples divorce, and people rely on government transfer payments.

To explore the connections between nuclear power, the mob, and levels of social capital, I construct two panel datasets. Some of the data are available at the level of the 47 prefectures, and some at the level of 1742 municipalities. I cover the years 1980 to 2010. I then study the relationship between the planning, construction, and operation of the nuclear plants, and crime rates, demographic characteristics, and proxies for local social capital.

The results are straightforward. When a power company announces a new reactor, the mob arrives and levels of extortion climb. Once the company clears regulatory hurdles and begins construction, that extortion stops. Simultaneously, however, young families begin to disappear. Social capital starts to crumble. Unemployment rises, transfer payments increase, and divorce rates climb.

I first survey the literature on organized crime generally (Sec. I.A., B.) and in Japan specifically (Sec. I.C.). I examine the peculiar ties among organized crime, the nuclear power industry, and social capital (Sec. II). Finally, I turn to the empirical results (Sec. III).

\section{Organized Crime}

A. The Genesis of the Mob:

1. Introduction. -- Firms in the mob everywhere extort money from rivals in the legal sector. They do so because -- largely for other reasons -- they invest heavily in the personnel, skills, and technology necessary to deliver violence. With that investment sunk, they exploit economies of scope and use the violence to extort.

On why mob firms invest in violence, scholars propose two explanations. Some suggest that they grew by selling property-rights protection in societies where the state protected those rights only weakly. Others suggest that they grew by selling goods and services in illegal sectors and invested in the violence necessary to protect these other investments. Given that the state does not protect property rights in sectors it defines as illegal, the two theories overlap. They also may just describe historical trajectories in different societies. The Sicilian mafia dates from a time when the Italian state lacked the power to protect property rights on the island. The American mob grew by selling alcohol during Prohibition.

Consider each explanation in turn.

2. Where the state is weak. -- The Sicilian mafia "produces, promotes, and sells private protection," writes Diego Gambetta (1993: 1). It protects property and enforces contracts for a fee. In the words of Stergios Skaperdas (2001: 174; see Kumar \& Skaperdas, 2008; Anderson, 1995), it holds protection as its "defining economic activity." Historically, it began in the market for protection and expanded into other industries over

\footnotetext{
${ }^{1}$ Whether reactors actually present these cancer risks from low-level radiation is not the issue here (see note 8, infra). What matters is that many Japanese believe they do.
} 
time. Analytically, it invested in resources crucial to the protection industry and exploited economies of scope to expand into industries adjacent to it.

Mobs everywhere protect property rights and enforce contracts; what distinguishes Sicily is the way they so consistently supply this service across the market for a fee. Elsewhere (as in the U.S., below), firms in illegal markets tend to build their own private enforcement capacity within their firm. In Sicily, the mob sells that protection to other firms. Its customers buy and sell goods and services on their own, but hire the mob to enforce the contractual terms they negotiate.

To deliver the service it sells, the Sicilian mafia uses violence. As Gambetta (1993: 2) put it, the firms use violence as "a means, not an end; a resource, not the final product." Contracting parties buy protection, and the mafia firms use their capacity for violence to provide that protection. The contracting parties buy the protection because they cannot trust their partners to perform voluntarily, and cannot trust the state to force them to perform involuntarily. Given that neither contracting partner trusts the other, "protection becomes desirable" (Gambetta, 1993: 2).

The economies of scale follow from the nature of violence itself. To enforce a contract effectively, a mob firm must be able to out-muscle the other party to its client's contract. It must be able to out-muscle any rival firm that the other party might hire for its own protection. And it must be able to hold the state at bay. Toward these ends, it will need a large capacity for violence. Only then will it earn a return on its investment.

For reasons peculiar to the transition from a feudal to openly competitive economy in western Sicily, the late 19th century Italian government failed to extend its control into the area. Residents took title to land, but could not trust the government to protect their lots. They developed businesses, but could not trust it to enforce their claims. Into that vacuum, men with a comparative advantage in violence sold protective services. $^{2}$

The demand for protection in a world of weak state power explains the rise of the mob in several other societies too (see Sung, 2004, for a comparative study). The Chinese triads, for instance, thrived during the decades of war. When foreign countries began to dismember China during the last half of the 19th century, the Manchu dynasty disintegrated. As it did, power moved to a shifting constellation of Nationalists, Communists, warlords, and the Japanese army. Within the resulting vacuum, the triads amassed their often brutal power (Wakeman, 1996).

The Russian mob similarly grew in the post-Soviet vacuum of state control. Entrepreneurs in the new environment needed a way to protect their property and enforce their contracts. Some had obtained their assets "from illegal shadow dealings in the Soviet era" and "were naturally unwilling to have any relations with the state police" (Volkov, 1999: 742). Even those without that dubious ancestry, though, found the new

${ }^{2}$ Gambetta (1993: ch. 4). See also, e.g., Arlacchi (1986: 26); Konrad \& Skaperdas (2012); Hess, 1996: 16); Andvig \& Fjeldstad (2001); Catanzaro (1992: x, 19); Anderson (1995). Some scholars (e.g., Gambetta, 1993: 77; Verese, 1994) have added that the mafia emerged not just because of a low level of state power, but because of the low level of trust among private residents. Trust is unusually low in southern Italy, they write. The mafia developed in response to that distrust. Of course, the level of local trust is obviously endogenous to what a mob chooses to do. Trust may be low in Sicily, but -- as Gambetta himself notes -- it is low in part because the mafia works to keep it that way. 
state hard to trust (Varese, 1994). Rather than rely on it, they hired enforcement services privately. Writes Vadim Volkov (1999: 746; see Skaperdas, 2001, 179):

Before signing formal business contracts, companies acquire information about each other's enforcement partners ("whom do you work with?") and arrange a meeting between enforcement partners (strelka)."

3. Where the market is illicit. -- The American "mafia" traces its origins to different historical patterns. The U.S. is not Sicily. The state is not weak, but even a strong state will not enforce property rights to transactions it declares illegal. When it bans a set of contracts, some participants to those transactions will turn to private protection services. As Gambetta (1993: 3) put it, "every time the state decrees a particular transaction or commodity illegal, a potential market for private protection is created." Hence the contrast: the Sicilian mafia arose in a world where the state did not enforce any property rights, legal or illegal; the U.S. mob developed within the illegal sectors of a world with a strong state. ${ }^{3}$

Effective 1920, American voters amended the Constitution to ban the sale of alcohol. Finding their drinks illegal, consumers turned to smuggled foreign liquor and domestic moonshine. Whether legal or illegal, alcohol will pass through several firms before reaching the consumer. The distiller will buy supplies. He will consign his product with a trucker who will deliver it to a wholesaler. The wholesaler will entrust it to another trucker who will transport it to a retailer. And the retailer will sell it to the consumer. Some parties will skip a step or two: a distiller may integrate vertically into shipping; a bar may buy directly from wholesaler. Other parties will add a few extra steps.

Because the U.S. government had declared the underlying product illegal, the participating firms needed a private capacity for violence. At each transactional node, they negotiated a contract. Yet virtually all these contracts were ones the state would not enforce. If a trucker stole the liquor, the consigning distiller could not call the police. If a distiller refused to pay for the transportation, the trucker could not sue. As a result, firms in the industry needed a private police force strong enough both to forestall state intervention, and to enforce private property and contractual rights.

Some of the best-known members of the American mob did come to prominence in Sicilian fashion by selling bootleggers protection by contract. Take Meyer Lansky and Benjamin "Bugsy" Siegel. The two first met as teenagers on the lower East Side of New York. They began in the gambling industry, but soon moved into contract enforcement in the alcohol distribution network. Together, they enforced the terms of their clients' transactions, and stole cargo from their clients' rivals. They bought equipment; they hired men willing to use it to maim and kill; they organized those men into teams; and they

${ }^{3}$ The Sicilian-U.S. contrast extends to a subsidiary question as well. The Sicilian mafia sold enforcement services to independent firms across the market. In the U.S., many of the early organized crime syndicates expanded by vertical integration from the market for the original illegal goods into that enforcement services industry. In other words, the Sicilian-U.S. contrast does not just concern the historical origins of the mob. It also concerns a question basic to industrial organization more generally: whether to buy or build -- whether to buy protection (as a requisite input to production) on the open market (as in Sicily), or to produce it within the firm (as in the U.S.) (see Dyck (1995), Garoupa (1999), and Fiorentini \& Peltzman (1995) for some of the transactions-cost considerations involved). 
bribed state agents (Messick, 1971: 23-31; Montague, 2005: 30-55). They then marketed their services to firms in the alcohol industry. Eventually -- but only several years later -they expanded into their own narcotics and large-scale gambling operations (Lacey, 1991: chs. 5-6; Messick, 1971: ch. 5).

Other firms in the American mob developed backwards. Lansky and Segal began as a specialty contract enforcement firm but expanded into other illegal services and products. Other firms began in illegal services and products, and expanded internally into private contract and property enforcement. Arnold Rothstein, for instance, started in the illegal service sector and developed his own private capacity for violence to protect his investments. Born in 1882, Rothstein was 31 when Prohibition began. He had already established a thriving gambling empire in New York, from floating craps games, to horse tracks and casinos. By 1919, he would famously fix the World Series (Pietrusza, 2003: chs. 3, 8, 11-12; Clarke, 1929: chs. 2-3).

As of 1920, Rothstein had become the central figure in the New York mob, what one historian would call "the J.P. Morgan of the underworld." ${ }^{4}$ To protect his gambling investments, he had grown within his own firms a capacity for violence. From this base in gaming, he expanded into alcohol and, eventually, narcotics (May, 2009: ch. 8). He did so (again) to exploit economies of scope. To enforce property rights in gambling, he had invested both (a) in the equipment, personnel, and organization necessary to supply violence, and (b) in the bribery necessary to corrupt city and state officials. Now, he could exploit those investments to expand into alcohol and narcotics.

Alphonse "Scarface Al" Capone similarly developed a capacity for violence to protect his investments in illegal service industries. For Capone, those illegal sectors had involved (here too) gambling, but also prostitution (Bergreen, 1994: ch. 2; Pasley, 1931: Pt. 1). There, he had acquired a reputation for an impulsive brutality extreme even by the standards of the Prohibition-era underworld. Exploiting the economies of scope to violence, from these early investments in gambling and prostitution he expanded into alcohol (Bergreen, 1994: ch. 3; Pasley, 1931: Pt. 7).

Modern inner-city gangs operate by much the same economic principles, albeit at a less sophisticated level. For the most part, they specialize in the retail narcotics market. To enforce contract and property rights, they invest in reputations for violence. To date, they only lightly diversify into other industries. When Steven Levitt and Sudhir Venkatech (2000) explored the finances of a major Chicago gang, they found both that the gang competed in few peripheral markets, and that it did not bribe city and state officials. It earned only trivial revenue from unrelated protection services, and apparently spent nothing on corrupting local police and politicians.

\section{B. Extortion:}

From their roots in either protection or other illegal markets, many mob firms diversify into extortion. Against private firms in the legal sector, they threaten violence and extract large amounts of wealth. The technology of violence being what it is, mobs that offer protection can easily expand into extortion. To supply protection, a mob firm will need equipment. It will buy guns and knives, and sometimes bombs. And it will

\footnotetext{
$\begin{array}{cccccc}4 & \text { Jewish } & \text { Virtual Library, } & \text { "Arnold } & \text { Rothstein." } & \text { Available at: }\end{array}$
} 
need personnel. It will hire young men willing and able to use its guns, knives, and bombs.

Once it invests in this equipment and personnel, a firm can use them as effectively to extort as to protect (e.g., Konrad \& Skaperdas, 2006, 2012; Skaperdas, 2001; Skarbeck, 2012). Economies of scope, in other words, transfer directly between the two activities. A well-equipped mob can use its equipment and personnel plausibly to promise to protect its clients from those who would harm them. It can use exactly the same equipment and personnel plausibly to extort pay-offs from non-clients in exchange for its agreeing not to harm them itself.

In most societies, the mob does indeed extort. Gambetta (1993) placed protection at the heart of the mob, but identified extortion as another activity in which it routinely engaged. Thomas Schelling (1967, 1971) placed extortion at its heart, and identified protection as another activity in which it routinely engaged: "the business of organized crime," declared he (1971: 647), "is extortion." No doubt it is a crucial distinction for some purposes; it is not one that matters here. ${ }^{5}$

\section{The Japanese Mob:}

1. Genesis. -- The mob in Japan reached its current power through a path similar to that in the U.S. This was not the Sicilian path. The state in Japan is not weak -- it is not weak now, and was not weak in the early post-war years. ${ }^{6}$ As under the U.S. Prohibition, the mob in Japan began in the illegal sector. Before the war, it had limited itself mostly to gambling. During the early post-war years, however, government bureaucrats intervened heavily in the economy. They had intervened rigidly during the war, and they did the same after its end. With their own New Deal bias, American occupation officials blithely encouraged them along (Miwa \& Ramseyer, 2005).

Initially, Japanese voters complied. They elected a Socialist prime minister in 1947, and let him implement the elaborate controls he wanted. The ensuing disasters followed textbook economics. Facing pervasive price controls, firms did not invest. They did not expand. They did not even sell. Instead, sellers hoarded. Massive shortages ensued, and sales shifted to the inevitable black market. On that illegal market the mob obtained its first stronghold (Hessler, 2012).

From this start, the mob moved quickly into methamphetamines. In the chaos of the early post-war years addiction ran rampant. The military had issued methamphetamines to its soldiers to induce them to fight. It had issued them to

\footnotetext{
${ }^{5}$ In most societies, the mob operates not just in illegal industries, but in several legal sectors as well -- and most commonly in sectors like construction that use low-skilled male labor and that turn on government contacts. To recruit workers, the mob can exploit its ties to the population from which it recruits its own members. To obtain government-related projects, it can exploit its investments (made to facilitate its illegal activities) in corrupting public officials. Fiorentini \& Peltzman (1995: 22) stress the mob's frequent "control over key input markets such as the labour market" in a variety of societies. Arlacchi (1986: 62-67, 96), Anderson (1995: 43), and Gambetta \& Reuter (1995: 122) discuss the mafia's ties to the construction industry in Sicily. Others show how the mob uses its control over American unions to manipulate the labor market more broadly (Skaperdas, 2001: 176; Gambetta \& Reuter, 1995). Fiorentini \& Peltzman (1995: 22) refer to the mob's ability to "manipulate the public procurement mechanism." And as Suzuki's (2011) account at the start of this article shows, the mob brokers labor services to construction projects in Japan as well.

${ }^{6}$ Harasyiw (2003) to the contrary notwithstanding.
} 
employees in support industries to induce them to work. When the war ended, the remaining stock shifted quickly onto the black market (Suwaki, Fukui \& Konuma, 1997: 201; Wada, 2011: 63).

Amid the pandemonium, methamphetamine abuse soared. At first, consumers took it in tablet form. Soon, they injected it intravenously. By 1954, abusers numbered 550,000, and increasingly committed high profile crimes. Methamphetamine usage fell in the mid-1950s, but heroin abuse took its place and continued into the 1960s (Suwaki, Fukui \& Konuma, 1997: 201-02; Wada, 2011: 63).

As with alcohol during Prohibition, consumers obtained their methamphetamine and heroin through an elaborate contractual chain: firms manufactured or imported the drug and sold it to wholesalers; the wholesalers shipped it and distributed it to retailers; the retailers offered and sold it to consumers. At every step, a contracting partner could default, renege, or cheat. At every step, rival market players could steal or disrupt.

The mob emerged by dominating this industry. Vertically integrated as in the U.S., mob firms in Japan manufacture, refine, ship, distribute, sell -- and enforce contractual terms through violence. Sicilian mafia firms sold enforcement (protection) to private parties on the market. Japanese mob firms produced enforcement services internally to protect their own contracts.

2. Current status. -- (a) Numbers. Police put the Japanese mob membership at 25,600. Under Japanese law, prefectural public safety commissions can and do designate the principal firms as organized crime firms. This results in the (perhaps misleadingly) precise talleys of group memberships. ${ }^{7}$ Add unreported affiliates and hangers-on and the 25,600 number doubles, and perhaps grows even more (Keisatsu cho, Hanzai hakusho, 2014, tab. 4-3-1-1). Of those members, half work for one of the three largest firms. Indeed, over 40 percent work for the largest of them all, the infamous Yamaguchi gumi (Table 1, Panel A).

[Insert Table 1 about here.]

These men are indeed the people Americans envision when they think of the "yakuza." In this case, the bizarre stereotypes are actually true. Many of the men do sport flamboyant full-body tattoos -- the practice may explain why so few other Japanese wear any tattoos at all. They may be missing a finger joint or two -- amputation is still the way to apologize for botching an assignment. They dress in loud suits, wear sunglasses indoors, and (if they can afford it) drive foreign cars.

Mob firms apparently earn the largest share of their revenues from methamphetamines. According to a now-dated 1989 police survey (Keisatsu cho, 1989: tab. 1-9), they earned 34.8 percent of their money from stimulants, and another 16.9 percent from gambling. They earned 8.7 percent from protection fees, and smaller amounts from prostitution. From legal sectors, they generated 19.7 percent.

Mob affiliates also find themselves arrested most often for crimes tied to this methamphetamine market. Police enforce the methamphetamine ban aggressively. A hapless American who arrives with prescription Adderall can find himself surrounded by the airport police. In 2013, police arrested 6,045 mob affiliates on methamphetamine-

\footnotetext{
${ }^{7}$ Boryokudan in ni yoru futo na koi no boshito ni kansuru horitsu [Act Concerning the Prevension of Improper Conduct Organized Crime Members], Law No. 77 of 1991.
} 
related charges. They also arrested 2,807 for battery, 2,470 for theft, 2,321 for fraud, and 1,084 for extortion (Table 1, Pan. B).

Mob affiliates dominate the arrests for some crimes. Police may arrest 2,470 affiliates for theft, but the affiliates do not dominate theft arrests. After all, police arrest huge numbers of people for theft who have no ties to the mob. But of the people they arrest on amphetamine-related charges, a majority comes from the mob. A majority of those they arrest for gambling-related charges comes from the mob. And a large fraction (though not majority) of those they arrest for blackmail and extortion has ties to the mob as well (Table 2, Sec. A).

[Insert Table 2 about here.]

As a result, for certain crimes, arrest data signal mob location. To be sure, police do not arrest everyone who commits a crime, and do not choose the criminals they arrest randomly. If under political pressure to suppress the mob, they will focus their efforts on mob members. If bribed to ignore the mob (though by all accounts police corruption is very low in Japan), they may focus on non-mob criminals. But subject to those caveats, arrest data for some crimes will identify the cities and towns where the mob operates most intensively. The point matters for this study, because the police release prefecturelevel crime data every year, but local mob membership only occasionally. They did release that membership data for 2011. In Table 2 Sec. B, I regress the number of crimes at the prefecture-level on mob membership and general population. As mob membership is obviously endogenous, consider these results a simple measure of correlation. As expected, the numbers of extortion, methamphetamine, and sex crimes in a prefecture correlate strongly with the number of mob members. The number of thefts does not.

(b) Membership. Most members of the Japanese mob are young, unskilled men who never took to schooling. According to the 1989 police white paper (Keisatsu cho, 1989), over 80 percent of mob members did not finish high school -- this in a country with a graduation rate over 95 percent. Of the members surveyed, 17 percent held regular jobs, 25.9 percent had irregular jobs, and 52.3 percent held no jobs at all.

Most mob members come either from the long-time underclass known as the burakumin (see Upham, 1987: ch. 3) or from the Korean resident alien community. In 1986, one pair of U.S. journalists cited the police for an estimate that 70 percent of the Yamaguchi gumi came from the underclass, and 10 percent from among the Koreans (Kaplan \& Dubro, 1986: 145; see also Kinsgston, 2013: 244). Twenty years later, a former official from the Public Security Intelligence Agency reported that 60 percent of the mob came from the underclass, and 30 percent from the Korean community. ${ }^{8}$ For years, observers studiously avoided mentioning the tie between the mob and the underclass. Increasingly, however, as police arrest prominent underclass leaders (including leaders of the famed Burakumin Liberation League), they disclose that the men concurrently held high-level posts in the mob (Mori, 2009). The ties between the two groups are simply too dense any longer to ignore.

The Japanese mob supplies some services that unwind dysfunctional government policy. Curtis Milhaupt and Mark West (2000) nicely identify several. Where tenant protection law stops developers from evicting tenants, for instance, the mob helps them

\footnotetext{
${ }^{8}$ Lecture by Mitsuhiro Suganuma, available at: http://www.youtube.com/watch?v=wNAJVnjlR2g
} 
skirt those legal restrictions. Where the bankruptcy regime introduces inefficiencies, the mob streamlines the process. That it sometimes remedies bad policy, however, should not distract from the essentially predatory nature of most of what it does.

II. Nuclear Power, the Mob, and Social Capital

A. Introduction:

This article turns on two propositions.

(A) The mob will extort funds most aggressively where firms make heavy site-specific, non-transferrable investments, and where the economic value of those investments can be expropriated through the political process. Of such investments, nuclear reactors constitute the quintessential example.

(B) The perceived risks from nuclear reactors fall with age. Those risks are primarily health risks, and involve conditions (particularly cancer) that appear only after many years. ${ }^{9}$ Necessarily, they present relatively small costs for residents already at retirement age. For young couples about to start a family, they pose much larger risks.

I explain these propositions in this Section II. I test them empirically in the following Section III.

\section{B. Nuclear Power and the Mob:}

1. Introduction. -- Nuclear plants-in-planning invite extortion and protection. They require the utility (heavily regulated but fundamentally a private corporation rather than government agency) to make massive site-specific investments: surveys, political and regulatory goodwill, licenses, and ton after ton of reinforced concrete. These investments entail huge costs. They do not transfer. And susceptible always to political nullification, they are regulatorily fragile. Table 3 details the facilities involved.

[Insert Table 3 about here.]

Take just the costs. Of all reactors in Japan, the cheapest has been Kansai Electric's first reactor at Mihama. Placed in service in 1970, it cost 31.2 billion yen. The most expensive was the Monju fast breeder reactor, placed in service in 1991 for 588.6 billion yen. The mean cost of construction for all reactors was 247 billion yen. The seven reactors at Tokyo Electric's massive Kashiwazaki complex on the Japan Sea cost a total of 2,576 billion yen (Denryoku, 2013).

At stake are the quasi-rents that these large site-specific investments necessarily create. Given those quasi-rents, the mob can take two steps. First, it can extort: it can threaten to fan public opposition to levels that will block the planned construction. Second, it can protect: it can offer to silence opponents who might otherwise threaten construction.

Rumors about extortion and protection have circulated for decades, but prominently hit the news post-Fukushima. As Suzuki (2011) noted at the start of this article, the mob sold protection by offering to silence the utility's opponents. The Yamaguchi-gumi and Sumiyoshi-kai allegedly extracted large sums from Tokyo Electric

\footnotetext{
${ }^{9}$ It is not clear that neighbors to nuclear power plants do incur a cancer risk. The U.S. Nuclear Regulatory Commission (obviously not a disinterested party) suggests not: "Although radiation may cause cancer at high dose rates, public health data do not absolutely establish the occurrence of cancer following exposure ot low doses and dose rates ...." (NRC, 2015).
} 
by threatening to disclose safety problems. ${ }^{10}$ And according to one journalist, a Tokyo Electric subcontractor testified in court that "it was standard practice to pay off local yakuza groups and politicians to obtain construction projects, including those in the nuclear industry." 11

2. Regulatory and political threats. -- If adamant enough, local residents can substantially hike the cost of a reactor and delay its operation, and potentially even kill it. Consider the delay from the time a utility announced its plans for a reactor, to the time it began operating it (see Table 3). For the first 10 reactors, the delay averaged 5.5 years. Primarily because of the growing opposition, by the time of the last 10 reactors that delay had climbed to 8.1 years.

For decades, the Ministry of Economy, Trade \& Industry (METI; formerly MITI) licensed the reactors. ${ }^{12}$ After choosing a site, a utility produced an environmental impact statement and assembled technical plans. It contacted METI, and the ministry consulted with the Nuclear Power Commission and the Nuclear Safety Commission. Once it obtained the necessary approvals, it started building. When finished, it submitted to still more inspections.

In order to convince residents to welcome a reactor, the national government offered lavish subsidies, jobs, and tax revenues (Aldrich, 2008: 119; Dusinberre \& Aldrich, 2011). Take a 2004 pamphlet METI published to generate support for new nuclear plants (Keizai, 2004). From the initial environmental impact statement to operation ten years later, it promised a community subsidies (in addition to jobs) of 39.1 billion yen. Once a plant went operational, it promised subsidies and revenues over the next ten years of 50.2 billion. To communities that agreed to accept nuclear waste sites, it promised even more.

Sometimes, militantly determined residents could kill a planned reactor. Obviously, they could protest and demonstrate. Assorted violent Trotskyite groups stood always ready to help (Keisatsu sho, Keisatsu hakusho, 2013). They (e.g., the Revolutionary Marxist Faction, or Kakumaru-ha) had their roots in the New Left student groups of the 1960s. During the 1970s, they had fought the new airport at Narita. More recently, they have turned to nuclear power. Throughout, though, they brought to their efforts a level of anarchic violence rarely seen in Japan.

Residents could elect anti-nuclear candidates to local governments. The national government might control the reactor license itself, but determined mayors, governors, and prefectural assemblies could stymie development in a nearly endless variety of ways.

${ }^{10}$ Adelstein, Nov. 19, 2012 (Yamaguchi gumi payoff); Adelstein, May 24, 2012 (Sumiyoshi kai payoff); Adelstein, Dec. 30, 2011.

${ }^{11}$ Adelstein, Dec. 30, 2011.

${ }^{12}$ See generally Cohen, McCubbins \& Rosenbluth (1995: 182-83); Genshiryoku (2003). The process follows statutes relating to the electrical power industry generally and to the nuclear power industry specifically: primarily, the Kaku genryo busshitsu, kaku nenryo busshitsu oyobi genshiryo no kisei ni kansuru horitsu [Law Regarding the Regulation of the Quality of Nuclear Raw Materials, Nuclear Fuel and Nuclear Reactors], Law No. 166 of 1957, Secs. 23, 24, 37, and the Denki jigyo ho [Electrical Business Act], Law No. 170 of 1964, Secs. 47, 49, 51, 52, 54, 107, and the Kankyo eikyo hyoka ho [Environmental Impact Evaluation Act], Law No. 81 of 1997. The process is still very much like the early 1990s process that Cohen, McCubbins \& Rosenbluth (1995) described. 
When Tokyo Electric built its Fukushima reactors, the governor held a veto (which he did not use) -- since the utility needed his permission to fill part of the local bay. ${ }^{13}$ When Tohoku Electric planned a reactor in Maki (Niigata prefecture), residents elected an antinuclear mayor. He promptly sold the site to an ally, and the ally refused to sell to the utility. ${ }^{14}$ Tohoku Electric challenged the transfer in court, but the judge sided with the town and the utility had no choice but to abandon its plans.

Residents could also call plebiscites (Kanbara, 1996). Their votes often had no legally binding effect, but if strongly enough opposed the residents could -- and sometimes did -- halt a utility's plans. They halted it, for example, when Tokyo Electric tried to use plutonium (far more dangerous than uranium) fuel in its Kashiwazaki plant. They held a plebiscite, and voted against allowing plutonium. They had no legal right to tell Tokyo Electric what fuel to burn, but facing fierce opposition the firm canceled its plans anyway (Jijiro, 2002; see also Saito, 2011).

3. Litigation. -- And opponents could embroil utilities in nearly endless litigation. The point is not that the opponents won the cases -- they usually lost. The point is not that the mob itself used the courts -- most plaintiffs seem to have brought left-leaning political loyalties. The point instead is that the scale of litigation reflected the strength of the opposition. That strength reflected the political vulnerability of the utilities. And that vulnerability, in turn, created the opportunity for the mob to manipulate local opposition and "hold up" the utility.

Anti-nuclear opponents had been fighting the Fukushima reactors in court since the early 1970s. ${ }^{15}$ In 1975, 400 local residents challenged Tokyo Electric's Fukushima operating license. They complained about earthquake risk, but the court declared that the regulators had properly weighed the risk and confirmed the license. ${ }^{16}$

Opponents also bought stock in Tokyo Electric and filed derivative suits. When the cooling system in one of the Fukushima reactors malfunctioned in 1989, they sued to shutter it. The court dismissed their claim for what amounted to the business judgment

${ }^{13}$ The governor did not use the veto, so local opponents challenged the land-fill permit in court. Onoda v. Matsudaira, 894 Hanrei jiho 39 (Fukushima D. Ct. June 19, 1978).

14 Takai v. Sasaguchi, 217 Hanrei chiho jiji 59 (Niigata D. Ct. Mar. 16, 2001) (dismissing challenge to sale), affirmed, 237 Hanrei chiho jiji 96 (Tokyo High Ct. Mar. 28, 2002). Genpatsu (2003) (Japan Communist Party newspaper); Tohoku (n.d.).

${ }^{15}$ In addition to the issues cited, opponents can embroil power companies in litigation over a wide range of other questions as well. They sue to block utilities from doing what they need to complete their license application: Iwo jima gyogyo kyodo kumiai v. Chugoku denryoku, K.K., 916 Hanrei taimuzu 237 (Yamaguchi D. Ct. Oct. 11, 1995) (land survey). They sue to block sympathetic governments from helping the utilities: Hashi v. Nakanishi, 1429 Hanrei jiho 46 (Kanazawa D. Ct. Mar. 22, 1991) (environmental impact statement); [No names given], 45 Gyosei jiken saibanrei shu 1112 (Asahikawa D. Ct. Apr. 26, 1994), aff'd, 48 Gyosai reishu 393 (Sapporo High Ct. May 5, 1997) (waste disposal study).

${ }^{16}$ Onoda v. Okonogi, 1124 Hanrei jiho 34 (Fukushima D. Ct. July 23, 1984), aff'd, 1345 Hanrei jiho 33 (Sendai High Ct. Mar. 20, 1990), affirmed, 1441 Hanrei jiho 50 (Sup. Ct. Oct. 29, 1992). The declaration is bizarre, of course, and not just ex post. Tokyo Electric had built the plant along a coast that regularly brought severe earthquakes and high tsunamis -- exactly as happened in 2011. See Ramseyer (2012). 
rule. $^{17}$ And when Tokyo Electric modified reactor 3 at the Daiichi plant to run on plutonium, opponents sued again. ${ }^{18}$

But opponents did not sue only over Fukushima; they sued nearly everywhere. Take the Shiga reactor complex on the Japan Sea shore. Anti-nuclear activists first sued to enjoin the operation of reactor 1 at the complex. In 1994, the district court noted the earthquake risk, but held the reactor safe anyway. ${ }^{19}$ They then sued over reactor 2 . The district court held in their favor in 2006, but the court on appeal reversed: the reactor was safe. ${ }^{20}$ Opponents similarly challenged licenses for the Ikata reactor (Ehime prefecture), the Tokai-mura reactor (Ibaragi), the Takahama reactor (Fukui), the Tomari-mura reactor (Hokkaido), the Kashiwazaki reactor (Niigata), the Monju fast breeder reactor (Fukui), and the Onagawa reactor (Miyagi). ${ }^{21}$ They challenged the license to a nuclear waste facility. ${ }^{22}$ And they challenged the license to an enrichment facility. ${ }^{23}$

Opponents did not just contest a reactor's safety. Sometimes they argued that the power company had filed inadequate disclosure statements. ${ }^{24}$ Sometimes they claimed

\footnotetext{
${ }^{17}$ Hirose v. Nasu, 1591 Hanrei jiho 3 (Tokyo D. Ct. Dec. 19, 1996), affirmed 1686 Hanrei jiho 33 (Tokyo High Ct. Mar. 25, 1999).

${ }^{18}$ [No name given] v. Tokyo denryoku, K.K., 1775 Hanrei jiho 114 (Fukushima D. Ct. Mar. 23, 2001) (Fukushima 1).

${ }^{19}$ Kawabe v. Hokuriku denryoku, K.K., 1515 Hanrei jiho 3 (Kanazawa D. Ct. Aug. 25, 1994), affirmed, 1656 Hanrei jiho 37 (Nagoya High Ct. Sept. 9, 1998), affirmed (Supreme Ct. Dec. 19, 2000).

${ }^{20}$ [No names given], 1930 Hanrei jiho 25 (Kanazawa D. Ct. Mar. 24, 2006); [No names given], 2045 Hanrei jiho 3 (Nagoya High Ct. Mar. 18, 2009), reversing (Kanazawa D. Ct. Mar. 24, 2006).

${ }^{21}$ Kawaguchi v. Fukuda, 891 Hanrei jiho 38 (Matsuyama D. Ct. Apr. 25, 1978)(Ikata), affirmed, Kawaguchi v. Murata, 1136 Hanrei jiho 3 (Takamatsu High Ct. Dec. 14, 1984), affirmed, Inoue v. Watanabe, 1441 Hanrei jiho 37 (Sup Ct. Oct. 29, 1992); [No name given], 1057 Hanrei taimuzu 87 (Matsuyama D. Ct. Dec. 15, 2000) (Ikata); Aizawa v. Murata, 1164 Hanrei jiho 3 (Mito D. Ct. June 25, 1985), affirmed in relevant part, 1754 Hanrei jiho 35 (Tokyo High Ct. July 4, 2001) (Tokai-mura); Smith v. Kansai denki, K.K., 1480 Hanrei jiho 17 (Osaka D. Ct. Dec. 24, 1993) (Takahama); Shigeno v. Hokkaido denryoku, K.K., 1676 Hanrei jiho 3 (Sapporo D. Ct. Feb. 22, 1999) (Tomari-mura); Nagasawa v. Kumagaya, 1489 Hanrei jiho 19 (Niigata D. Ct. Mar. 24, 1994), affirmed, 52 Somu geppo 1581 (Tokyo High Ct. Nov. 22, 2005) (Kashiwazaki); Isobe v. Takeshita, 1264 Hanrei jiho 31 (Fukui D. Ct. Dec. 25, 1987), reversed, 1322 Hanrei jiho 33 (Nagoya High Ct. July 19, 1989), modified, Tokioka v. Miyazawa, 1437 Hanrei jiho 29 (Sup Ct. Sept. 22, 1992) (Monju); [No name given], 1727 Hanrei jiho 33 (Fukui D. Ct. Mar. 22, 2000), reversed, 1818 Hanrei jiho 3 (Nagoya High Ct. Jan. 27, 2003), reversed, 1909 Hanrei jiho 8 (Sup. Ct. May 30, 2005) (Monju); Abe v. Tohoku denryoku, K.K., 1482 Hanrei jiho 3 (Sendai D. Ct. Jan. 31, 1994), affirmed, 1680 Hanrei jiho 46 (Sendai High Ct. Mar. 31, 1999) (Onagawa).
}

These are just the published opinions. News reports indicate that neighbors have sued in other cases as well. The Oct. 26, 2007, decision of the Shizuoka District Court in the litigation over the Hamaoka reactor can be found on the website of the plaintiffs: www.geocities.jp/ear_tn/.

${ }^{22}$ [No name given], 1278 Hanrei taimuzu 97 (Aomori D. Ct. June 16, 2006).

${ }^{23}$ [No names given], 1102 Hanrei taimuzu 79 (Aomori D. Ct. Mar. 15, 2002), affirmed, Hanrei taikei 28131668 (Sendai High Ct. May 9, 2006).

${ }^{24}$ Abe v. Tohoku denryoku, K.K., 1452 Hanrei jiho 3 (Sendai D. Ct. Mar. 12, 1993) (disclosure required), affirmed, 1460 Hanrei jiho 38 (Sendai High Ct. May 12, 1993), affirmed, Hanrei taikei 28060382 (Sup. Ct. Dec. 19, 2000); Miki v. Kawaguchi, 786 Hanrei jiho 3 (Takamatsu High Ct. July 17, 1975) (disclosure required); Aizawa v. Prime Minister, 43 Somu geppo 1522 (Tokyo High Ct. Dec. 25, 1996) (disclosure not required). 
procedural irregularities. ${ }^{25}$ As at Fukushima, sometimes opponents bought stock and filed derivative suits. ${ }^{26}$ Sometimes they (as shareholders) attended the annual meetings, disrupted the proceedings, and then sued to vacate the meeting on the ground that management had paid them insufficient attention. ${ }^{27}$ At least once, they argued that using land for nuclear power violated the "public order and good morals" requirement of the Civil Code. ${ }^{28}$ And twice they claimed that a utility's planned site was held "in common" by all members of the village, and that each therefore held a veto over the sale of the land to the utility. ${ }^{29}$

4. The mob. -- After Fukushima, reporters started to look more closely at the role organized crime played in the nuclear industry. In 2011, for example, freelance journalist Tomohiko Suzuki turned to the Fukushima cleanup. He applied for a job on the crew, and arrived at the site to work (Suzuki, 2011). There, he found the mob involvement he detailed at the start of this article. He spotted some of the men by the famously flamboyant full-body tattoos that he noticed as they changed into and out of their protective gear. They told him that they took the Fukushima job for a simple reason: they needed work, and the job paid well. "For women it's sex, and for men it's nuclear power," went the apparent aphorism. ${ }^{30}$ "When a man has to survive doing something, it's the nuclear industry," explained one journalist. "[F]or a woman, it's the sex industry." ${ }^{31}$

Other cleanup workers were not themselves members of the mob, but told Suzuki they had obtained the job through it. Usually unemployed, they lived homeless or in a seedy section of large city. They knew their local mob representatives, and the representatives knew them. Those representatives introduced them to Tokyo Electric, and collected an under-the-table fee for doing so.

Recent arrests corroborate Suzuki's account. In 2012, police arrested a member of the Sumiyoshi kai mob for brokering workers to the Fukushima cleanup without a

${ }^{25}$ Oba v. Japan, 1741 Hanrei jiho 139 (Hakodate D. Ct. July 13, 2000).

${ }^{26}$ Nakagawa v. Abe, 1652 Hanrei jiho 138 (Nagoya D. Ct. Mar. 19, 1998).

${ }^{27}$ Matsushita v. Kyushu denryoku, K.K., 1392 Hanrei jiho 126 (Fukuoka D. Ct. May 14, 1991); Nakagaki v. Chubu denryoku, K.K., 116 Shiryoban shoji homu 188 (Nagoya D. Ct. Sept. 30, 1993); Shinohara v. Tohoku denryoku, K.K., 109 Shiryo ban shoji homu 64 (Sendai D. Ct. Mar. 24, 1993); Kobayashi v. Hokkaido denryoku, K.K., 109 Shiryo ban shoji homu 56 (Sapporo D. Ct. Feb. 22, 1993).

${ }^{28}$ See Minpo [Civil Code], Law No. 89 of 1896, Sec. 90; see Shikoku denryoku, K.K. v. Tamura, 728 Hanrei jiho 27 (Matsuyama D. Ct. Feb. 2, 1974).

${ }^{29}$ [No names given], 1918 Hanrei jiho 58 (Aomori D. Ct. May 10, 2005); [No name given] v. Chugoku denryoku, K.K., 1933 Hanrei jiho 84 (Hiroshima High Ct. Oct. 20, 2005), affirmed, 2007 Hanrei jiho 58 (Sup. Ct. Apr. 14, 2008). See generally Commentary, 1269 Hanrei taimuzu 121 (2008). See also Shibano v. Tokyo denryoku, K.K., 1361 Hanrei jiho 3 (Niigata D. Ct. July 18, 1990) (Kashiwazaki reactor; in commons litigation, all villagers are necessary parties). 58bd.html.

${ }^{30}$ Quoted occasionally on the web. E.g., http://eulabourlaw.cocolog-nifty.com/blog/2011/05/post-

${ }^{31}$ Adelstein, Dec. 30, 2011. 
license. $^{32}$ They arrested a member of the smaller Matsuba kai mob for the same crime in October 2014 (e.g., Genpatsu (2014a, 2014b).

In fact, the mob had brokered workers to construction projects for years. The phenomenon is not and never was limited to Fukushima. The police arrested a member of the Kyushu-based Kudo kai in 2012 for brokering labor to Kansai Electric's Ooi nuclear plant. And when in 2011 the President of Hakushin Construction tried to cut the firm's ties to a local Kyushu crime syndicate, mob members shot him dead outside his home. $^{33}$

\section{Nuclear Power and Social Capital:}

Wholly aside from the mob, nuclear plants take a toll on communities through their effect on young families. Traditionally, residents did not fear the reactors primarily because of the risk of Fukushima-style meltdowns. They feared them because the diseases (mostly cancers) that they worried the reactors would cause. ${ }^{34}$

These radiation risks presented apparent costs that correlated inversely with age: necessarily, they fell hardest on the young. Residents did not think that low-level radiation would cause cancer in a year; they worried that it might cause cancer after several decades. This presented a potentially enormous cost to a thirty-year-old couple nursing a small infant; it suggested a much smaller cost to an elderly couple with only a decade or two left to live anyway. In exchange for accepting a reactor, METI promised lavish subsidies and tax revenues. The young couple was relatively less likely to think the cash could offset the cancer risk to them or their child; the elderly couple was relatively more likely to take the risk for the money.

Crucially, when young families leave a community, they cause the level of social capital to plummet. In any society, it is the families with young children who invest most heavily in the social ties that hold the community together. Older couples may bring attitudes that value community, but as they age they withdraw and live increasing isolated lives. Older couples do not volunteer for the PTA. They do not coach middle-school baseball teams, help at the local library, or upbraid incipient delinquents on the street. Young parents do. They -- not the retired couples -- contribute in the countless other ways that help a community cohere. It is the "families with children," writes political scientist Charles Murray, who stand at "the core" of well-functioning communities (Murray, 2012, 165).

Several consequences follow. Once a local utility announces plans for a reactor, new young families will not move to the area. Existing families will leave. As the most stable and committed young couples disappear, the divorce rate will climb. As employers begin to identify the community as fragile, they will locate their plants and offices elsewhere. Unemployment will climb, and -- ever so steadily -- the community will begin to disintegrate.

32 See Adelstein, Jan. 24, 2013; Adelstein, May 24, 2012; Adelstein, May 22, 2012; Adelstein, Dec. 30, 2011.

${ }^{33}$ Adelstein, May 22, 2012; see Suzuki (2011: 31); Adelstein, supra, May 24, 2012; Adelstein, supra, May 24, 2012; Adelstein, supra, Dec. 30, 2011.

\footnotetext{
${ }^{34}$ It could not have helped that the reactors attracted mob members as well.
} 
III. The Empirical Inquiry

A. Introduction:

1. The project. -- The two propositions above suggest the following testable hypotheses:

(1) Once a utility announces plans for a new reactor, the level of extortion should rise. The number of mob members will increase. They will come to extort money from the utility, but stay to extort funds from other firms too.

fall.

(2) Once the firm obtains its license and starts construction, extortion will

For most communities, accepting a nuclear plant is something of a Faustian bargain. The plant will not just invite extortion. Because it imposes the largest perceived costs on young families, it will threaten social capital more generally.

(3) To be sure, government transfer payments will increase as promised.

(4) But because new parents worry most about radiation, the community will lose young families.

(5) Because the most stable and committed young couples will disappear, the level of social capital will fall and divorce rates will climb.

(6) And as social capital falls, employers will stay away and unemployment will rise.

To test these hypotheses, I take for my dependent measure several indices of crime and social capital. As my principal independent measures, I use dichotomous variables equal to 1 if either that municipality or an adjacent municipality is (a) planning, (b) building, or (c) operating a nuclear plant. I use a fixed-effect regression (the Hausman test indicates that a random-effects model would be inappropriate), and employ a municipality-level data set spanning three decades. Because the municipality-level data do not disaggregate the data by type of crime, I also use a prefecture-level panel dataset as appropriate.

2. Preliminary qualifications. -- Note several qualifications at the outset. First, the logic behind hypotheses (1) and (2) does not apply only to nuclear plants. Instead, it covers many large-scale projects. Airports, dams, and new SDF bases can raise the same dilemmas. As the mob member noted at the start of the article:

There's nothing special involved. A huge public project comes to a tiny town. That's really all there is to it. Dams and highways are exactly the same.

I nonetheless focus on nuclear plants both because of the scale involved and because of the distinctive effect they have on social capital (on hypotheses (3) through (6)). Nuclear plants involve massive outlays -- and generate correspondingly large quasirents for the utility. They carry spectacular risks -- and generate correspondingly fervent opposition. Although similar in many ways to dams, highways, airports, and self-defense force (SDF) bases, they differ in scale. What is more, reactors destroy social capital in a way that dams, highways, and SDF bases do not. Nuclear reactors drive young families away from the community -- with the consequences for social capital explored below. Dams, highways, and SDF bases do not.

Second, the decision to build a nuclear plant in a community is endogenous. Utilities do not site reactors randomly. They want them along the coast for access to water. Communities do not accept them randomly either. For all the reasons noted 
above, the communities that agree to take them are those with a high fraction of elderly residents. I discuss this issue more fully in Sec. III.C.3, below.

Third, I do not count extortion claims only against the utility. Instead, I count all extortion claims reported to the police. Note the dynamic: once a utility announces its plans for a reactor, it becomes extraordinarily vulnerable to extortion; the mob moves in to exploit that vulnerability; and once local, the mob does what it does everywhere -extort money from local businesses. In other words, the spike in the extortion rate that one observes when a utility announces its plans does not only (or even mostly) represent extortion against the utility. Rather, it reflects the mob's arrival in the community.

Last -- and most obviously -- because I take my count of extortion cases from the police, they represent extortion attempts that failed. If a local business quietly pays the mob, it will seldom report it to the police. The police will learn of extortion attempts only when the business reports it to the police, or when the mob retaliates publicly against a recalcitrant firm.

B. Variables:

1. Panel construction. -- I run fixed effect regressions on prefecture-level and municipality-level panel datasets. The data cover all 47 prefectures in Japan, and all 1,742 cities, towns, and villages. Because Japan has no unincorporated areas, the two datasets cover the entire country. I include all 31 years from 1980 to 2010.

2. Nuclear plants. -- I measure the effect of nuclear plants through three key independent variables. They indicate whether the power company has announced its plans for a nuclear plant, whether it has begun construction, and whether it has started to operate the reactor. If a municipality has an operating reactor and announces plans for an additional one, I ignore the new reactor and simply code the municipality as having an operating plant. Because the risks to a reactor cross city lines, I code a municipality has having a reactor if a reactor is present either in the municipality itself or in an adjacent municipality. I take the information from Genshiryoku (2013: 14-17) (see Table 3 for detail).

Plan announced: 1 if a power company has announced plans to build a nuclear plant in the municipality or any adjacent municipality (or prefecture).

Construction begun: 1 if a power company has begun construction of a nuclear plant in the municipality or any adjacent municipality (or prefecture).

Operational: 1 if a power company has begun operating a nuclear plant in the municipality or any adjacent municipality (or prefecture).

For the prefecture-level regressions of Table 5, I ask whether the reactor is in that specific prefecture (not an adjacent prefecture). 
3. Other variables. -- I take the other municipality-year panel variables from several government sources. ${ }^{35}$ For each variable, I calculate the per capita measure by the population statistics given in Somusho, Kokusei (various years), and give the value per 1000 population (see Table 4).

[Insert Table 4 about here.]

Under 15 PC: The number of people under age 15, per capita. Data from the Somusho, Kokusei (various years).

Over 64 PC: The number of people over age 64, per capita. Data from Somusho, Kokusei (various years).

Births PC: The number of births, per capita. Data from Kosei, Jinko (various years).

Deaths PC: The number of deaths, per capita. Data from Kosei, Jinko (various years).

In-migration PC: The number of in-migrants, per capita. Data from Somusho, Jumin (various years).

Marriages PC: The number of marriages, per capita. Data from Kosei, Jinko (various years).

Divorce rate: The number of divorces, divided by the number of marriages. Note: this number is not per 1000 marriages. Data from Kosei, Jinko (various years). I measure the divorce rate as divorces/marriages rather than divorces/population simply to follow scholarly custom in the field.

Revenue PC: Municipal revenues (sainyu kessan sogaku), per capita. Data from Somusho, Shichoson (various years).

Unemployment rate: Number of unemployed workers, divided by the 15-65 year-old population. The calculation applies only to workers over age 15, and excludes those who deliberately opt out of the organized labor market. Data from Somusho, Kokusei (various years).

Crimes PC: The number of non-traffic-related Criminal Code violations (keiho han ninchi kensu), per capita. Data from Keisatsu cho (various years). These are overwhelmingly thefts, as explained in Sec. III.C.2(c), below.

35 The data can be downloaded from the standard government website http://www.estat.go.jp/SG1/chiiki/ToukeiDataSelectDispatchAction.do. 
3. Prefecture-level variables. -- Because the municipal-level data do not distinguish among crimes, in Table 5 I run the regressions on prefecture-level data. I use the following variable:

Extortion PC: The number of "sobo" crimes, per capita: extortion, blackmail, assembly with a dangerous weapon, assault, and battery. Data from Keisatsu cho (various years). These crimes are heavily associated with the mob.

\section{Regressions:}

1. Extortion. -- In Panel A of Table 5, I regress (a) the level of extortion per capita over 1980-2010 on (b) several independent variables that reflect reactor siting. Because data disaggregated by crime are not available at the municipality level, I use a prefecture-level dataset. In fact, that limitation presents less of a problem than one might think. Mobs will not usually extort funds from a power company in the coastal village where it actually builds the reactor. They will approach it instead at its local headquarters.

In Regression (1), I use prefecture fixed effects. In Regression (2), I add year fixed effects as well. The qualitative results do not differ.

[Insert Table 5 about here.]

When a utility announces plans to build a reactor, the mob arrives and tries to extort funds from it. While present in the community, it extorts funds from other local businesses as well. According to Table 5 Panel A, the coefficient on the announcement of a plan is positive and statistically significant in both regressions. ${ }^{36}$ When the firm obtains its license and starts construction, the number of extortion cases falls. Given that the utility has obtained the permits necessary to build the plant, it is now less vulnerable to the mob. Given that the mob often brokers unskilled labor to construction projects (as Suzuki's (2011) account at the start of the article reflects), however, it may be earning a cut of the utility's labor bill. By one account, mob firms generally take a 3 percent cut on public-sector construction projects (Kingston, 2013: 245).

Panel B gives the actual level of extortion involved. During the years before the utility announces its plans for a new reactor, these towns had mean per capita (crimes per 1000 population) extortion rates of .277 . Once the company announced its plans, that rate rose to .440. It fell to .318 during construction, and stayed at .329 once operation commenced.

Once a utility begins to operate the reactor, Regression (2) suggests that extortion rates fall below their initial level. Note, however, that this phenomenon appears only with the inclusion of year fixed effects. It does not appear in Regression (1). Neither does it appear in the period averages in Panel B. According to those figures, extortion rates after a reactor begins operation remain higher than before the utility initially announced its plans to built it.

2. Social capital. -- (a) Demographics. Nuclear plants change a community, and in problematic ways. As explained in Sec. II.C., perceived radiation risks fall most

${ }^{36}$ The results are insignificant in the regressions with year fixed effects if I extend the period back to 1975 . Note that significant coefficients do not appear on the (generally mob-related) crimes involving stimulants or the sex industry. 
heavily on the young. Other than the catastrophic meltdown, the perceived harm (largely, a cancer risk) accrues over decades. For couples with young children, the risks can seem huge. For couples already retired (and, to put it crassly, a decade or two from death anyway), they will be more modest. Should a community accept a reactor, older couples may not much care. Younger parents will find it a less attractive place to raise their family (an instinct probably aggravated by the arrival of the mob).

Table 6 reflects this dynamic. Once a power company announces plans to build a reactor, young families disappear. The fraction of children under age 15 per capita falls while the fraction of people over 64 rises (Table 6). The fraction of births falls while the fraction of deaths rises. The coefficients on the age variables are significant and robust to the inclusion of year fixed effects (Table 6 Pan. B). The coefficients on the number of births become insignificant with the year fixed effects, but the coefficients on the number of deaths per capita remain robust. The rate at which people move into the community may also fall when a community builds a reactor (Pan. A), though the results disappear with the introduction of year fixed effects (Pan. B).

[Insert Table 6 about here.]

(b) Divorce, government revenue, and unemployment. The reactor's effects on local social capital go farther. Families with young children maintain the most extensive ties within the community. As they disappear, social cohesion declines. According to Table 7, marriage rates fall and divorce rates rise. The decline in marriage rates appears strongly in Panel A, but disappears with the inclusion of year fixed effects in Panel B. The increase in divorce rates, however, is robust to the inclusion of year fixed effects. In Panel A, the positive coefficients are significantly positive for all three periods. In Panel $\mathrm{B}$, they are significantly positive during the plan announcement period, and nearly significant during the construction period as well.

[Insert Table 7 about here.]

As promised, the reactor brings the local government enormous revenue. The coefficients on government revenue are large and significant in Panel A. In the Panel B regression with year fixed-effects, they are nearly significant during the plan announcement period, and become massive once construction begins. The revenues remain high after the reactor turns operational.

And as a community accepts a reactor, unemployment rates rise. In the Panel A regression of unemployment rates on reactor variables, the coefficients are positive and significant in all periods. In Panel B, the inclusion of year fixed-effects limits the significantly positive coefficients to the first period. As the young families disappear and social capital falls, employers apparently disappear too -- and unemployment levels rise. During construction, the utility hires large numbers of young men, and this may explain the insignificant coefficient on the period in Panel B. Unemployed workers will leave in search of jobs elsewhere, and this in turn may explain the insignificant coefficient on the operational period in Panel B.

(c) The crime rate puzzle. When a community begins operating a reactor, general crime rates fall. Although crime rates climb in the Panel A regressions without year fixed effects, they fall with the inclusion of those effects in Panel B. This rate, however, does not reflect mob crimes. Instead, it primarily captures thefts. In 1980, 1.17 million of the 
1.36 million crimes in Japan (i.e., Criminal Code violations) were thefts. In 2010, 1.57 million of the 1.78 million crimes were thefts. In effect, the regressions of Crimes PC in Table 7 mostly represent regressions of the number of thefts per capita.

Thefts are not a mob crime. In a typical year, less than two percent of the people police arrest for theft are members of a mob. Instead, the theft rate in a community reflects the fraction of young people more generally. As the reactors drive young families away, the fraction of adolescent boys in the community falls (see Table 6, Reg (1)), and the rate of theft declines.

3. Endogeneity. -- Power companies do not select the sites for their nuclear reactors randomly (see generally Aldrich, 2008, 2012; Dusinberre \& Aldrich, 2011). Neither do communities accept the reactors randomly. The power companies need access to water to cool the reactors. In France, they build their reactors along the Rhine. In Japan, they build them by the sea.

In deciding whether to accept a proposed reactor, communities face a trade-off. On the one hand, if they choose to let the utility build the reactor, they receive the enormous infusion of cash: initial subsidies and continuing property tax revenues. With that cash, they can buy facilities and services they could not otherwise afford. On the other, communities incur the perceived risk of radiation (and the accompanying hit to social capital captured in Tables 6 and 7). As discussed (Sec. II.C.), the costs to these risks fall with age. Disproportionately, they fall hardest on the young.

Predictably, the communities that choose to take the subsidies at the cost of the radiation risk are old. At the time of the siting announcement, they are also communities with lower crime and divorce rates -- but those characteristics simply reflect resident age. In Table 8, I use probit regressions to explore which communities decide to accept a nuclear reactor. In each case, the dependent variable is equal to 1 if the municipality accepted a reactor over the course of 1980-2010. The independent variables represent community values as of 1980 . The only consistently significant result appears on the fraction of the population that dies in any year -- a proxy for fraction that is elderly. The older the community, the more likely it will opt to accept a reactor.

[Insert Table 8 about here.]

This result is also consistent with Aldrich's (2008, 2012) hypothesis that utilities site reactors in the communities lease able to organize. Because people withdraw as they age, elderly couples have fewer ties within the community than younger couples. Aldrich (2008, 2012) argues that they find it harder to organize against a planned reactor, and the results in Table 8 are consistent with this hypothesis.

\section{Conclusions}

Nuclear reactors entail massive non-transferrable site-specific investments. In turn, the resulting appropriable quasi-rents offer the mob the ideal target. It can promise to "protect" the utility, and take money for silencing the reactor's local opponents. Alternatively, it can "extort" from the utility, and take money for not inciting local opponents. Prefecture-level panel data from 1980 to 2010 confirm this phenomenon. When a utility announces plans to build a reactor, the mob moves in, and the level of extortion per capita climbs. 
The reactor has more broad-ranging, debilitating effects on social capital as well - as the municipality-level data show. The costs imposed by a local reactor correlate inversely with age. As a result, when a utility announces plans for a reactor, young families disappear. Death rates rise, birth rates fall, and the fraction of elderly residents climbs. Reliance on government subsidies increases, divorce rates climb, and unemployment rises. 


\section{Table 1: Organized Crime -- Selected Statistics (I)}

A. Largest Criminal Organizations

\begin{tabular}{llr} 
& Headquarters & $\begin{array}{c}\text { Formal } \\
\text { Membership }\end{array}$ \\
\hline Yamaguchi gumi & Kobe & 11,600 \\
Sumiyoshi kai & Tokyo & 4,200 \\
Inagawa kai & Tokyo & 3,300 \\
Matsuba kai & Tokyo & 910 \\
Kyokuto kai & Tokyo & 880 \\
Dojin kai & Kurume, Fukuoka & 630 \\
Kudo kai & Kita-kyushu, Fukuoka & 560 \\
& & \\
Total formal (registered) membership & 25,600
\end{tabular}

Source: Keisatsu cho, Heisei 26 nen johanki no boryokudan josei [The Situation of Organized Crime in the First Half of 2014] (Tokyo: Keisatsu cho, 2014), p. 21.

\section{B. Most Common Arrests of Organized Crime Members}

$\begin{array}{lr}\text { Stimulants } & 6, \odot 45 \\ \text { Battery } & 2,807 \\ \text { Theft } & 2,470 \\ \text { Fraud } & 2,321 \\ \text { Extortion } & 1,084 \\ & \\ \text { Total arrests } & 22,861\end{array}$

Source: Keisatsu cho, Heisei 26 nen johanki no boryokudan josei [The Situation of Organized crime in the First Half of 2014] (Tokyo: Keisatsu cho, 2014), pp. 3, 6. 


\section{Table 2: Organized Crime -- Selected Statistics (II)}

A. Crimes with Largest Fraction of Arrests Involving Mob

\begin{tabular}{llcl} 
& Mob Arrests & Total Arrests & $\%$ \\
\hline Horse racing & 14 & 14 & 100 \\
Bicycle racing & 34 & 35 & 97.1 \\
Gambling & 511 & 876 & 58.3 \\
Stimulants & 6285 & 11379 & 55.2 \\
False imprisonment & 201 & 424 & 47.4 \\
Blackmail & 1334 & 3050 & 43.7 \\
Opiates & 543 & 1576 & 34.5 \\
Extortion & 617 & 2145 & 28.8
\end{tabular}

Source: Homu sho, Hanzai hakusho [Crime White Paper] (Tokyo: Homu sho, 2013), Tab. 4-2-2-2.

B. Selected Crimes and the Location of the Mob

\begin{tabular}{|c|c|c|c|c|}
\hline & \multicolumn{4}{|c|}{ Dependent variable: } \\
\hline & Extortion & $\begin{array}{l}\text { Stimulant } \\
\text { crimes }\end{array}$ & $\begin{array}{l}\text { Sex } \\
\text { Crimes }\end{array}$ & Theft \\
\hline & $\begin{array}{l}.119 * * * \\
(3.11)\end{array}$ & $\begin{array}{l}.059 * * \\
(2.47)\end{array}$ & $\begin{array}{l}.037^{* * *} \\
(2.97)\end{array}$ & $\begin{array}{l}1.151 \\
(1.18)\end{array}$ \\
\hline Population & $\begin{array}{l}5.26^{* * *} \\
(14.96)\end{array}$ & $\begin{array}{l}1.40^{* * *} \\
(6.33)\end{array}$ & $\begin{array}{l}.752^{* \star *} \\
(6.49)\end{array}$ & $\begin{array}{l}110.0^{* * *} \\
(12.30)\end{array}$ \\
\hline Adj. R2 & .96 & .86 & .88 & .94 \\
\hline
\end{tabular}

Notes: Coefficients, followed by the absolute value of the t-statistic in parentheses. The regressions are OLS. Data are at the prefectural level, with $\mathrm{n}=47$. Crime data are from 2010; mob membership is as of 2011. Extortion is "sobo" crimes, as discussed in the text. Total crimes are as defined in the text. Population is 110,000 .

Sources: Crime data are from Keisatsu sho (2011), available from estat.go.jp. Mob membership is from Todofuken (2013). 
Table 3: Nuclear Reactors

\begin{tabular}{|c|c|c|c|}
\hline Reactor & $\begin{array}{c}\text { Plans } \\
\text { Announced }\end{array}$ & $\begin{array}{c}\text { Construction } \\
\text { Began }\end{array}$ & $\begin{array}{l}\text { Operatior } \\
\text { Commenced }\end{array}$ \\
\hline Tokai, Ibaraki & 1959 & 1961 & $1966 a$ \\
\hline Tsuruga 1, Fukui & 1965 & 1967 & 1970 \\
\hline Mihama 1, Fukui & 1966 & 1967 & 1970 \\
\hline Fukushima Daiichi 1, Fuk'ma & 1966 & 1967 & 1971 \\
\hline Fukushima Daiichi 2, Fuk'ma & 1968 & 1969 & 1974 \\
\hline Mihama 2, Fukui & 1968 & 1968 & 1972 \\
\hline Takahama 1, Fukui & 1969 & 1970 & 1974 \\
\hline Fukushima Daiichi 3, Fuk'ma & 1969 & 1970 & 1976 \\
\hline Hamaoka 1, Shizuoka & 1969 & 1971 & 1976 \\
\hline Shimane 1, Shimane & 1969 & 1970 & 1974 \\
\hline $0 i 1$, Fukui & 1970 & 1972 & 1979 \\
\hline $0 i 2$, Fukui & 1970 & 1972 & 1979 \\
\hline Unkai 1, Saga & 1970 & 1971 & 1975 \\
\hline Takahama 2, Fukui & 1970 & 1971 & 1975 \\
\hline Onagawa 1, Miyagi & 1970 & 1971 & 1984 \\
\hline Mihama 3, Fukui & 1971 & 1972 & 1976 \\
\hline Fukushima Daiichi 5, Fuk'ma & 1971 & 1971 & 1978 \\
\hline Fukushima Daiichi 4, Fuk'ma & 1971 & 1972 & 1978 \\
\hline Hamaoka 2, Shizuoka & 1972 & 1973 & $1978 b$ \\
\hline Ikata 1, Ehime & 1972 & 1973 & 1977 \\
\hline Fukushima Daiichi 6, Fuk'ma & 1972 & 1973 & 1979 \\
\hline Fukushima Daini 1 , Fukushima & 1972 & 1975 & 1982 \\
\hline Tokai 2, Ibaragi & 1972 & 1973 & 1978 \\
\hline Unkai 2, Saga & 1974 & 1976 & 1981 \\
\hline Kashiwazaki 1, Niigata & 1974 & 1978 & 1985 \\
\hline Fukushima Daini 2, Fukushima & 1975 & 1979 & 1984 \\
\hline Ikata 2, Ehime & 1975 & 1977 & 1982 \\
\hline Kawauchi 1, Kagoshima & 1976 & 1978 & 1984 \\
\hline Fukushima Daini 3, Fukushima & 1977 & 1980 & 1985 \\
\hline Kawauchi 2, Kagoshima & 1978 & 1981 & 1985 \\
\hline Takahama 3, Fukui & 1978 & 1980 & 1985 \\
\hline Takahama 4, Fukui & 1978 & 1980 & 1985 \\
\hline Fukushima Daini 4, Fukushima & 1978 & 1980 & 1987 \\
\hline Hamaoka 3, Shizuoka & 1978 & 1982 & 1987 \\
\hline Tsuruga 2, Fukui & 1979 & 1982 & 1987 \\
\hline Kashiwazaki 2, Niigata & 1981 & 1983 & 1990 \\
\hline Kashiwazaki 5, Niigata & 1981 & 1983 & 1990 \\
\hline Shimane 2, Shimane & 1981 & 1984 & 1989 \\
\hline
\end{tabular}

(Continued on next page.) 
Table 3: Nuclear Reactors (Continued)

\begin{tabular}{lccc} 
Reactor & $\begin{array}{c}\text { Plans } \\
\text { Announced }\end{array}$ & $\begin{array}{c}\text { Construction } \\
\text { Begins }\end{array}$ & $\begin{array}{c}\text { Operation } \\
\text { Commences }\end{array}$ \\
\hline Unkai 3, Saga & 1982 & 1985 & 1994 \\
Unkai 4, Saga & 1982 & 1985 & 1997 \\
Oki 1, Hokkaido & 1982 & 1984 & 1989 \\
Oki 2, Hokkaido & 1982 & 1984 & 1991 \\
Monju, Fukui & 1983 & 1985 & 1994 \\
Ikata 3, Ehime & 1983 & 1986 & 1994 \\
Kashiwazaki 3, Niigata & 1985 & 1987 & 1993 \\
Kashiwazaki 4, Niigata & 1985 & 1987 & 1994 \\
Oi 3, Fukui & 1985 & 1987 & 1991 \\
Oi 4, Fukui & 1985 & 1987 & 1993 \\
Hamaoka 4, Shizuoka & 1986 & 1988 & 1993 \\
Shiga 1, Ishikawa & 1987 & 1988 & 1993 \\
Onagawa 2, Miyagi & 1987 & 1989 & 1995 \\
Kashiwazaki 6, Niigata & 1988 & 1991 & 1996 \\
Kashiwazaki 7, Niigata & 1988 & 1991 & 2002 \\
Onagawa 3, Miyagi & 1994 & 1996 & 2005 \\
Totsu 1, Aomori & 1996 & 1998 & 2005 \\
Hamaoka 5, Shizuoka & 1997 & 1999 & 2006 \\
Shiga 2, Ishikawa & 1997 & 1999 & 2009 \\
Oma, Aomori & 1999 & 2008 & \\
Oki 3, Hokkaido & 2000 & 2003 & \\
Shimane 3, Shimane & 2000 & 2005 & \\
Kamiseki 1, Yamaguchi & 2001 & & \\
Kamiseki 2, Yamaguchi & 2001 & & \\
Tsuruga 3, Fukui & 2002 & & \\
Tsuruga 4, Fukui & 2002 & & \\
Totsu 1, Aomori & 2006 & 2011 & \\
Totsu 2, Aomori & 2006 & & \\
Tota & & &
\end{tabular}

a. Decommissioned 2001.

b. Decommissioned 2009 .

Source: Genshiryoku anzen kiban kiko, ed., Genshiryoku shisetsu unten kanri nempo [Supervision of Nuclear Facilities Operation Annual] (Tokyo: Genshiryoku anzen kiban kiko, 2013). 
Table 4: Selected Summary Statistics

\begin{tabular}{llllll} 
& $\mathrm{n}$ & Min & Mean & Median & Max. \\
\hline Extortion PC* & 1,457 & .103 & .356 & .321 & 1.03 \\
Under 15 PC & 54,001 & 42.5 & 171 & 166 & 353 \\
Over 64 PC & 54,001 & 36.8 & 190 & 179 & 572 \\
Births PC & 54,001 & $\odot$ & 9.37 & 9.20 & 39.0 \\
Deaths PC & 54,001 & 0 & 9.10 & 8.69 & 69.7 \\
InMigration PC & 26,129 & 2.05 & 38.7 & 35.3 & 322 \\
Marriage PC & 54,001 & $\odot$ & 5.11 & 5.04 & 30.8 \\
Divorce rate & 53,916 & $\odot$ & .289 & .266 & 4.00 \\
Unemployment PC & 54,001 & $\odot$ & 40.2 & 35.6 & 294 \\
Crimes PC & 48,592 & $\odot$ & 9.85 & 8.60 & 122 \\
Revenues PC & 54,001 & 106,339 & 441,080 & 387,800 & $11,843,290$
\end{tabular}

\footnotetext{
Notes: * Prefecture-level. All values other than those for the divorce rate are per 1000 population.
}

Sources: See text. 
Table 5: Nuclear Power and Crime

A. Regressions:

Dependent variable: Extortion $P C$

\begin{tabular}{lll}
\hline Plan announced & $(1)$ & $(2)$ \\
& $.148^{* *}$ & $.052^{* *}$ \\
Const 'n begun & $(3.92)$ & $(2.00)$ \\
& .049 & -.014 \\
Operational & $(1.38)$ & $(0.56)$ \\
& .019 & $-.053^{* *}$ \\
& $(0.59)$ & $(2.29)$ \\
$\mathrm{n}$ & 1457 & \\
F test & 24.27 & 1457 \\
Year fixed effects & No & 51.49 \\
& & Yes
\end{tabular}

B. Extortion PC:

Mean Extortion PC for pre-planning period: .277

Mean Extortion PC during planning: 440

Mean Extortion PC during construction: $\quad .318$

Mean Extortion PC during operation: $\quad .329$

Notes: $*, * *, * * *$ : significance at 10,5 and 1 percent levels. Prefecture-level fixed effect regressions, with coefficient, followed by absolute value of the $t$ statistic. $F$ test that all $\mathrm{Ui}=0$. The independent variables are equal to 1 if that prefecture has a reactor. Years 1980-2010.

Sources: See text. 
Table 6: The Effects of Nuclear Power on Demographics

A. Without Year-Fixed Effects:

\begin{tabular}{llllll} 
Dependent variable: Under & Over & Births & Deaths & InMig \\
& $15 P C$ & $64 P C$ & $P C$ & $P C$ & $P C$ \\
\hline \multirow{3}{*}{ Plan announced } & $(1)$ & $(2)$ & $(3)$ & $(4)$ & $(5)$ \\
& $-50.0^{* *}$ & $80.1^{* * *}$ & $-1.94^{* * *}$ & $2.84^{* * *}$ & $-6.38^{* * *}$ \\
Const'n begun & $(10.83)$ & $(10.94)$ & $(6.95)$ & $(11.04)$ & $(4.13)$ \\
& $-45.5^{* * *}$ & $55.0^{* * *}$ & $-1.34^{* * *}$ & $1.89^{* * *}$ & $-6.79^{* * *}$ \\
Operational & $(11.34)$ & $(8.65)$ & $(5.55)$ & $(8.46)$ & $(3.09)$ \\
& $-92.3^{* * *}$ & $140.2^{* * *}$ & $-4.26^{* * *}$ & $3.72^{* * *}$ & $-14.9^{* * *}$ \\
& $(23.82)$ & $(22.86)$ & $(18.25)$ & $(17.20)$ & $(5.82)$ \\
n & & & & & \\
F test & 54,001 & 54,001 & 54,001 & 54,001 & 26,129 \\
& 11.35 & 30.51 & 19.98 & 54.89 & 82.06
\end{tabular}

B. With Year Fixed Effects:

\begin{tabular}{llllll} 
Dependent variable: Under & Over & Births & Deaths & InMig \\
& $15 P C$ & $64 P C$ & $P C$ & $P C$ & $P C$ \\
\hline \multirow{3}{*}{ Plan announced } & $(1)$ & $(2)$ & $(3)$ & $(4)$ & $(5)$ \\
& $-.9 .78^{* * *}$ & $14.6^{* *}$ & -.038 & $1.27^{* * *}$ & -1.22 \\
Const'n begun & $(6.97)$ & $(6.20)$ & $(0.23)$ & $(7.03)$ & $(0.93)$ \\
& $-19.2^{* * *}$ & $11.7^{* * *}$ & -.082 & $.767^{* * *}$ & 2.26 \\
Operational & $(15.81)$ & $(5.75)$ & $(0.58)$ & $(4.90)$ & $(1.22)$ \\
& $-12.4^{* * *}$ & $20.7^{* * *}$ & -.047 & $.810^{* * *}$ & -.777 \\
& $(10.52)$ & $(10.43)$ & $(0.34)$ & $(5.32)$ & $(0.36)$ \\
n & & & & & \\
F test & 54,001 & 54,001 & 54,001 & 54,001 & 26,129 \\
& 119.82 & 292.77 & 58.64 & 111.64 & 115.23
\end{tabular}

Notes: $*, * *, * * *$ : significance at 10,5 and 1 percent levels. Coefficient, followed by absolute value of the $\mathrm{t}$-statistic. $\mathrm{F}$ test that all $\mathrm{Ui}=0$. The independent variables are equal to 1 if that or an adjacent municipality has a reactor. Years 1980-2010.

Sources: See text. 
Table 7: The Effects of Nuclear Power on Social Capital

A. Without Year Fixed Effects:

\begin{tabular}{llllll} 
Dependent variable: & Marriage & Divorce & Revenues & Unempl & Crimes \\
& $P C$ & rate & $P C @$ & $P C$ & $P C$ \\
\hline & $(1)$ & $(2)$ & $(3)$ & $(4)$ & $(5)$ \\
Plan announced & $-.403^{* * *}$ & $.174^{* * *}$ & $148^{* * *}$ & $19.2^{* * *}$ & $1.423^{* * *}$ \\
& $(3.27)$ & $(8.80)$ & $(5.36)$ & $(11.34)$ & $(2.57)$ \\
Const'n begun & $-.226^{* * *}$ & $.099^{* * *}$ & $199^{* * *}$ & $9.17^{* * *}$ & -.289 \\
& $(2.11)$ & $(5.76)$ & $(8.29)$ & $(6.24)$ & $(0.59)$ \\
Operational & $-.950^{* * *}$ & $.186^{* * *}$ & $464^{* *}$ & $23.4^{* * *}$ & $1.127^{* *}$ \\
& $(9.19)$ & $(11.27)$ & $(20.03)$ & $(16.49)$ & $(2.38)$ \\
n & & & & & \\
F test & 54,001 & 53,916 & 54,001 & 54,001 & 48,592 \\
& 37.38 & 5.73 & 108.11 & 21.41 & 49.54
\end{tabular}

B. With Year Fixed Effects:

\begin{tabular}{|c|c|c|c|c|c|}
\hline Dependent variable & $\begin{array}{l}\text { Marriage } \\
P C\end{array}$ & $\begin{array}{l}\text { Divorce } \\
\text { rate }\end{array}$ & $\begin{array}{l}\text { Revenues } \\
\text { PC@ }\end{array}$ & $\begin{array}{l}\text { Unempl } \\
P C\end{array}$ & $\begin{array}{l}\text { Crimes } \\
P C\end{array}$ \\
\hline & (1) & (2) & (3) & (4) & (5) \\
\hline Plan announced & $\begin{array}{r}-.032 \\
(0.29)\end{array}$ & $.051^{* * *}$ & $\begin{array}{l}34.6 \\
(1.60)\end{array}$ & $\begin{array}{l}4.895^{* * *} \\
(6.72)\end{array}$ & -.648 \\
\hline & $\begin{array}{l}.041 \\
(0.43)\end{array}$ & $\begin{array}{l}.022 \\
(1.62)\end{array}$ & $\begin{array}{l}121.3^{* * *} \\
(6.49)\end{array}$ & $\begin{array}{l}-.041 \\
(0.06)\end{array}$ & $\begin{array}{l}-1.269^{* * *} \\
(3.17)\end{array}$ \\
\hline Operational & $\begin{array}{l}-.042 \\
(0.45)\end{array}$ & $\begin{array}{l}-.0 \odot 8 \\
(\odot .61)\end{array}$ & $\begin{array}{l}176.7^{* * *} \\
(9.75)\end{array}$ & $\begin{array}{l}-.444 \\
(0.73)\end{array}$ & $\begin{array}{l}-1.860^{* * *} \\
(4.84)\end{array}$ \\
\hline $\mathrm{n}$ & 54,001 & 53,916 & 54,001 & 54,001 & 48,592 \\
\hline F test & 46.05 & 8.95 & 178.14 & 114.94 & 75.98 \\
\hline
\end{tabular}

Notes: $*, * *, * * *$ : significance at 10,5 and 1 percent levels. Coefficient, followed by absolute value of the $\mathrm{t}$-statistic. $\mathrm{F}$ test that all $\mathrm{Ui}=0$. The independent variables are equal to one if that or an adjacent municipality has a reactor. @ These coefficients are per capita rather than per 1000 capita. Years 1980-2010.

Sources: See text. 
Table 8: Nuclear Reactor Siting

\begin{tabular}{|c|c|c|c|c|c|}
\hline Dependent variable: & $\begin{array}{l}\text { Reactor } \\
\text { (1) }\end{array}$ & $\begin{array}{r}\text { sited } \\
(2)\end{array}$ & (3) & (4) & (5) \\
\hline Unempl PC & $\begin{array}{l}11.89 \\
(1.13)\end{array}$ & & $\begin{array}{l}-21.52 \\
(0.78)\end{array}$ & $\begin{array}{l}-21.22 \\
(0.75)\end{array}$ & $\begin{array}{l}-21.43 \\
(0.75)\end{array}$ \\
\hline Crimes PC & & $\begin{array}{l}-175.4^{*} \\
(1.76)\end{array}$ & $\begin{array}{l}-75.61 \\
(0.65)\end{array}$ & $\begin{array}{l}-71.32 \\
(0.56)\end{array}$ & $\begin{array}{l}-75.43 \\
(0.59)\end{array}$ \\
\hline Births PC & & & $\begin{array}{l}-31.69 \\
(0.37)\end{array}$ & $\begin{array}{l}-44.84 \\
(0.41)\end{array}$ & $\begin{array}{l}-45.45 \\
(0.41)\end{array}$ \\
\hline Deaths PC & & & $\begin{array}{l}224.1^{* *} \\
(2.43)\end{array}$ & $\begin{array}{l}219.7^{* *} \\
(2.37)\end{array}$ & $\begin{array}{l}221.2^{* *} \\
(2.37)\end{array}$ \\
\hline Marriage PC & & & & $\begin{array}{l}2.494 \\
(0.01)\end{array}$ & $\begin{array}{l}2.601 \\
(0.01)\end{array}$ \\
\hline Divorce rate & & & & $\begin{array}{l}-.919 \\
(0.27)\end{array}$ & $\begin{array}{l}-.922 \\
(0.27)\end{array}$ \\
\hline Population & & & & & $\begin{array}{l}8.13 \mathrm{e}-07 \\
(0.41)\end{array}$ \\
\hline Pseudo R2 & 0.31 & 0.12 & 0.37 & 0.38 & 0.37 \\
\hline $\mathrm{n}$ & 1724 & 1514 & 1514 & 1512 & 1512 \\
\hline
\end{tabular}

Notes: The dependent variable is equal to 1 if the municipality without a reactor announced plans for a reactor during 1980-2010. Regressions are probit, variables are 1980 values, and coefficients are per capita rather than per 1000 capita.

$*, * *, * * *$ : significance at 10,5 and 1 percent levels. Coefficient, followed by absolute value of the $t$ statistic. $F$ test that all $\mathrm{Ui}=0$.

Sources: See text. 


\section{Bibliography}

Adelstein, Jake. 2011. The Yakuza and the Nuclear Mafia: Nationalization Looms for TEPCO, Dec. 30, 2011. Available at: http://www.thewire.com/global/2011/12/yakuza-and-nuclear-mafianationalization-looms-tepco/46803/.

Adelstein, Jake. 2012. First Arrest Made Linking Yakuza with Fukushima Nuclear Clean-Up Crews, May 22, $2012 . \quad$ Available at: http://www.thewire.com/global/2012/05/first-arrest-made-linkingyakuza-fukushima-nuclear-clean-crews/52649/.

Adelstein, Jake. 2012. How the Yakuza and Japan's Nuclear Industry Learned to Love Each Other, May 24, $2012 . \quad$ Available at: http://www.thewire.com/global/2012/05/how-yakuza-and-japans-nuclearindustry-learned-love-each-other/52779/.

Adelstein, Jake. 2012. When the Yakuza Come Calling, One in Five Japanese Companies Admit to Paying Them Off, Nov. 19, 2012. Available at: http://www.thewire.com/global/2012/11/when-yakuza-come-calling-onefive-japanese-companies-admit-paying-them/59056/

Adelstein, Jake. 2013. Silence Is Cost of Freezing a Yakuza Group's U.S. Assets, Jan. 24, 2013. Available at: http://www.thewire.com/global/2013/01/silencecost-freezing-yakuza-groups-us-assets/61365/.

Albini, Joseph L. 1971. The American Mafia: Genesis of a Legend (New York: Appleton-Century-Crofts, 1971).

Aldrich, Daniel P. 2008. Site Fights: Divisive Facilities and Civil Society in Japan and the West. Ithaca: Cornell University Press.

Aldrich, Daniel P. 2012. Networks of Power: Institutions and Local Residents in PostTohoku Japan. In Jeff Kingston, ed., Natural Disaster and Nuclear Crisis in Japan. London: Rutledge, pp. 127-39.

Alexander, Barbara. 1997. The Rational Racketeer: Pasta Protection in Depression Era Chicago, 40 J.L. \& Econ. 175 (1997).

Anderson, Annelise. 1995. Organized Crime, Mafia and Governments. In Fiorentini \& Peltzman (1995: 33).

Andvig, Jens Chr. \& Odd-Helge Fjeldstad. 2001. Corruption: A Review of contemporary Research, Chr. Michelson Institute R2001:7 (2001).

Arlacchi, Pino. 1986. Mafia Business: The Mafia Ethic and the Spirit of Capitalism (London: Verso, 1986).

Backhaus, Juergen. 1979. Defending Organized Crime? A Note, 8 J. Legal Stud. 623 (1979).

Bergreen, Laurence. 1994. Capone: The Man and the Era. New York: Simon \& Schuster.

Blok, Anton. 1974. The Mafia of a Sicilian Village, 1860-1960 (London: Oxford University Press, 1974).

Buchanan, James. 1973. A Defense of Organized Crime. In S. Rottemberg, ed., The Economics of Crime and Punishment. Washington, D.C.: American Enterprise Institute. 
Catanzaro, Raimondo. 1992. Men of Respect: A Social History of the Sicilian Mafia (New York: Free Press, 1992).

Clarke, Donald Henderson. 1929. In the Reign of Rothstein. New York: Vanguard.

Cohen, Linda, Mathew McCubbins \& Frances Rosenbluth. 1995. The Politics of Nuclear Power in Japan and the United States. In Peter Cowhey \& Mathew McCubbins, eds., Structure and Policy in Japan and the United States. New York: Cambridge University Press, pp. 177-202.

Denryoku gaisha ni, "genshiryoku hatsudensho no kensetsuhi wa ikura desuka?" to kiite meta [I asked the Electric Companies how much a Nuclear Power Generator cost], Mainabi nyuusu, Mar. 15, 2013.2 Available at: http://news.mynavi.jp/news/2013/03/15/100/.

Dusinberre, Martin \& Daniel P. Aldrich. 2011. Hatoko Comes Home: Civil Society and Nuclear Power in Japan. J. Asian Stud., 70: 683-705.

Dyck, Andrew R. 1995. When Does Organized Crime Pay? A Transaction Cost Analysis, Int'l Rev. L. \& Econ., 15: 25-45 (1995).

Fiorentini, Gianluca \& Sam Peltzman. 1995. Introduction. In Fiorentini \& Peltzman (1995: 1).

Fiorentini, Gianluca \& Sam Peltzman. 1995. The Economics of Organized Crime (Cambridge: Cambridge University Press, 1995).

Gambetta, Diego \& Peter Reuter. 1995. Conspiracy Among the Many: The Mafia in Legitimate Industries. In Fiorentini \& Peltzman (1995: 116).

Gambetta, Diego. 1988. Fragments of an Economic Theory of the Mafia, 29 Archives Europeennes de Sociologie, (1988), p. 127.

Gambetta, Diego. 1993. The Sicilian Mafia: The Business of Private Protection (Cambridge: Harvard University Press, 1993).

Garoupa, Nuno. 1999. Optimal Law Enforcement and Criminal Organization, March 1999 working paper.

Genpatsu baburu ni tayoranai machi ye [Toward a Town that Will Not Rely on the Nuclear Power Bubble], Shinbun akahata, Dec. 31, 2003.

Genpatsu sagyoin haken de boryokudanin taiho [Mob Arrest for Forwarding Workers to Nuclear Power Work], Oct. 6, 2014 (2014a). Available at: http://ai.2ch.sc/test/read.cgi/newsplus/1412584555/.

Genpatsu sagyoin haken de Matsubakaikei boryokudanin taiho [Arrest of Mob Member Affiliated with Matsuba kai for Forwarding Workers to Nuclear Power Work]. Oct. 6, 2014 (2014b). Available at: http://benzaiten.dyndns.org/roller/ugya/entry/matsubakai-2014.

Genshiryoku anzen kiban kiko, ed. 2013. Genshiryoku shisetsu unten kanri nempo [Supervision of Nuclear Facilities Operation Annual]. Tokyo: Genshiryoku anzen kiban kiko.

Genshiryoku hatsuden gijutsu kiko, Genshiryoku hatsudensho no anzen shinsa [The Safety Inspection of Nuclear Reactor Generating Plants] (2003).

Grossman, Herschel I. 1995. Rival Kleptocrats: the Mafia versus the State. In Fioretini \& Peltzman (1995: 143).

Harasyiw, Bohdan. 2003. Putting Organized Crime in Its Place ... Within Political Science. Canadian Pol Sci. Assn. June 2003. 
Hess, Henner. 1996. Mafia \& Mafiosi: Origin, Power and Myth (New York: New York University Press, 1996).

Hessler, Peter. 2012. All Due Respect. New Yorker, Jan. 9, 2012.

Hill, Peter. Oxford UP on the mob.

Hobsbawm, E.J. 1959. Primitive Rebels: Studies in Archaic Forms of Social Movement in the 19th and 20th Centuries. New York: Praeger, 1959).

Jijiro Kashiwazaki shi shokuin rodo kumiai rengo kai, Niigata ken Kashiwazaki Kirihama genpatsu 3 goki no purusaamaru jisshi no kahi wo tou jumin dohyo wo meguru genchi hokoku [Site Report on the Plebecite over the use of MOX in Reactor 3 at the Niigata Prefecture Kashiwazaki Kirihama Reactor 3] (2002). Available at: www.jichiro.gr.jp/jichiken/report/rep_tokushima29/jichiken/5/5_2_02.htm.

Kanbara, Maki cho genpatsu jumin tohyou to jumin sanka [Resident Plebicites and Resident participation on Maki Nuclear Reactor], Hogaku seminaa, p. 22, Nov. 1996.

Kaplan, David E. \& Alec Dubro. 1986. Yakuza: The Explosive Account of Japan's Criminal Underworld. Reading, MA: Addison-Wesley.

Keisatsu cho, Heisei 26 nen johanki no boryokudan josei [The Situation of Organized Crime in the First Half of 2014]. Tokyo: Keisatsu cho, 2014.

Keisatsu cho. Various years. Hanzai tokei [Crime Statistics]. Tokyo: Keisatsu cho.

Keisatsu cho. Various years. Keisatsu hakusho [Police White Paper] (Tokyo: Keisatsu cho).

Keizai sangyo sho shigen enerugiii cho, Dengen ricchi seido no gaiyo -- Heisei 15 nendo daikaiseigo no aratana kofukin seido [An Outline of the Electrical Generating Sites -- The New Subsidy System After the Great Revision of 2003], Mar. 2004, www.dengen.or.jp.

Kingston, Jeff. 2013. Contemporary Japan, 2d ed. West Sussix, U.K.

Konrad, Kai A. \& Stergios Skaperdas. 1997. Credible Threats in Extortion, J. Econ. Behav. \& Org., 33: 23-39 (1997).

Konrad, Kai A. \& Stergios Skaperdas. 2006. The Market for Protection and the Origin of the State (2006).

Konrad, Karl A. \& Sterglos Skaperdas. 2012. The market for Protection and the Origin of the State, 50 Econ. Theory 417-443 (2012).

Kosei rodo sho. Various years. Iryo shisetsu chosa [Survel of Medical Establishments]. Tokyo: Kosei rodo sho.

Kosei rodo sho. Various years. Ishi shikaishi yakuzaishi chosa [Survey of Physicians, Dentists, and Pharmacists]. Tokyo: Kosei rodo sho.

Kosei rodo sho. Various years. Jinko dotai tokei [Vital Statistics of Japan]. Tokyo: Kosei rodo sho.

Kreps, David M., Paul Milgrom, John Roberts \& Robert Wilson. 1982. Rational Coopeation in the Finitely Repeated Prisoners' Dilemma, 27 J. Econ. Theory 24552 (1982).

Kugler, Maurice, Thierry Verdier \& Yves Zenou. 2005. Organized Crime, Corruption and Punishment, J. Pub. Econ. 89: 1639-1663 (2005).

Kumar, Vimal \& Stergios Skaperdas. 2008. On the Economics of Organized Crime (2008). 
Lacey, Robert. 1991. Little Man: Meyer Lansky and the Gangster Life. Boston: Little, Brown \& Co.

Levitt, Steven D. \& Sudhir Alladi Venkatesh. 2000. An Economic Analysis of a DrugSelling Gang's Finances, QJE, 115: 755-789 (2000).

May, Allan R. 2009. Gangland Gotham. Santa Barbara: Greenwood.

Mehlum, Halvor, Karl Moene \& Ragnar Torvik. 2000. Predator or Prey? Parasitic Enterprises in Economic Development, University of Oslo, Econ. Dept. WP 200027.

Messick, Hank. 1971. Lansky. New York: G.P. Putnam \& Sons.

Milhaupt, Curtis J. \& Mark D. West. 2000. The Dark Side of Private Ordering: An Institutional and Empirical Analysis of Organized Crime, 67 Univ. Chicago L. Rev. 41-98 (2000).

Miwa, Yoshiro \& J. Mark Ramseyer. 2005. The Good Occupation. Harvard Law School Disc. Paper 514, available from SSRN, abstract=729463.

Montague, Art. 2005. Meyer Lansky. Canmore, Alberta: Altitude.

Mori, Isao. 2009. Dowa to ginko [Burakumin and the Bank]. Tokyo: Kodansha.

Murray, Charles. 2012. Coming Apart: The State of White America, 1960-2010. New York: Crown Forum.

NRC. 2015. Radiation Exposure and Cancer. Available at: http://www.nrc.gov/aboutnrc/radiation/health-effects/rad-exposure-cancer.html.

Pasley, Fred D. 1931. Al Capone. N.P.: Ives Washburn.

Pietrusza, David. 2003. Rothstein. New York: Carroll \& Graf.

Ramseyer, J. Mark. 2012. Why Power Companies Build Nuclear Reactors on Fault Lines: The Case of Japan. Theoretical Inquiries L., 13: 457.

Saito, Makoto. 2011. Ansatsu shirei [Assassination Order], 1796 Bessatsu takara jima 112, 116.

Schelling, Thomas C. 1967. Economics and Criminal Enterprise, Pub. Interest, 7: 61 (1967).

Schelling, Thomas C. 1971. What Is the Business of Organized Crime?, Am. Scholar, 40: 643-652 (1971).

Siniawer, Eiko. Yakuza book. Wms College hist.

Skaperdas, Stergios. 2001. The Political Economy of Organized Crime: Providing Protection when the state does not." 2 Econ. Gov. 173-202.

Skarbek, David. 2012. Prison Gangs, Norms, and Organizations, J. Econ. Behav. \& Org., 82: 96-109 (2012).

Somusho. Various years. Jumin kihon daicho jinko ido hokoku nempo [Annual Report Regarding Population Movements on Basic Resident Registry]. Tokyo: Somucho.

Somusho. Various years. Kokusei chosa hokoku [Population Census]. Tokyo: Somusho.

Somusho. Various years. Shichoson betsu kessan jokyo cho [Municipality-Level Budgetary Circumstances]. Tokyo: Somusho.

Sung, Hung-En. 2004. State Failure, Economic Failure, and Predatory Organized Crime: A Comparative Analysis, 41 J. Res. Crime \& Delinquency 111 (2004).

Suwaki, Hiroshi, Susumu Fukui \& Kyohei Konuma. 1997. Methamphetamine Abuse in Japan: Its 45 Year History and the Current Situation, in Hilary Klee, ed., 
Amphetamine Misuse: International Perspectives on Current Trends (Amsterdam: Overseas Publishers Assn, 1997).

Suzuki, Tomohiko. 2011. Yakuza to genpatsu [Yakuza and Nuclear Power]. Tokyo: Bungei shunju.

Todofuken betsu boryokudan koseiinnto rankingu [Ranking of Mob Members by Prefecture]. 2013. (data as of 2011). Available at: http://www.nicotwitter.com/watch/nm19944499.

Tohoku denryoku kabushiki gaisha Maki genshiryoku hatsudensho no genshiryo setchi kyoka shinsei no torisage ni tsuite [Regarding the Withdrawl of the Application for the Establishment of a Nuclear Reactor Electrical Generator at Maki by Tohoku Electric Power Co.]. Available at METI website: www.meti.go.jp/kohosys/press/0004934/.

Upham, Frank K. 1987. Law and Social Change in Postwar Japan. Cambridge: Harvard University Press.

Varese, Federico. 1994. Is Sicily the Future of Russia: Private Protection and the Rise of the Russian Mafia, Archives of European Sociology, 35: 224-58 (1994).

Volkov, Vadim. 1999. Violent Entrepreneurship in Post-Communist Russia, 51 EuropeAsia Stud. 741-754 (1999).

Wada, Kiyoshi. 2011. The History and Current State of Drug Abuse in Japan, Ann. N.Y. Academy of Sciences, vol. 1216: 62 (2011).

Wakeman, Frederic. 1996. Policing Shanghai, 1927-1937 (Berkeley: University of California Press, 1996). 